\title{
TRAINING OF PROFESSIONAL DIVERS AT THE UNDERWATER POLYGON
}

\author{
Tamara STANCIU \\ tamara.stanciu@navy.ro
}

Adriana AGAPE

agape.adriana@yahoo.com

Laurențiu MOCANU

laurentiu.mocanu@navy.ro

Nicușor CHIRIPUCI

nicusor.chiripuci@navy.ro

DIVING CENTER, CONSTANȚA, ROMANIA

\begin{abstract}
The underwater polygon for training of professional divers is a major multi-annual project of the Romanian Naval Forces, underway since 2020, as part of the EUNDC, in the European PESCO program. The paper presents the main challenges encountered in the development of the polygon and the constructive solutions resulting from the work of the research team of the Diving Center from Constanța.
\end{abstract}

\section{KEYWORDS:}

Polygon, divers, missions, abilities

\section{Introduction}

Romania's participation in the working groups of the European Defense Agency (EDA) has contributed to the promotion and affirmation of our country as a potential provider of professional training in the field of divers at European level, this being the main objective of the project, Permanent Structured Cooperation (PESCO) project, approved by Council Decision (CFSP) 1909 of 12 November 2019.
The project is initiated by Romania, with Romania, Bulgaria and France as participating Member States and Spain as an observer. The creation of a network of diving centers coordinated by our country for the certification and training of divers at EU level, based on common standards and procedures, as well as their certification for European missions, requires the modernization of the traditional Romanian Navy Diving Center. 
The modernization plan also includes a complex underwater polygon, which will rise to the level of the training bases of the allied naval forces. The training ground must ensure the continuous training of professional divers, at international standards, for the creation of the reflexes and automatisms necessary in the development of the underwater activities that they carry out. The development of this training ground is a major step in order to improve training support and alignment with international requirements in the field of professional training of divers.
2. Missions, requirements and capabilities of the underwater polygon

\subsection{Types of missions performed in the diving range}

The training ground for divers must ensure the intense, diversified and continuous training of all types of divers for the specific missions of the groups in this category of forces. The national structures that are composed of groups of divers prepared for the Diving Training, Training and Training Course within the Diving Center from Constanţa are represented in (Figure no. 1).

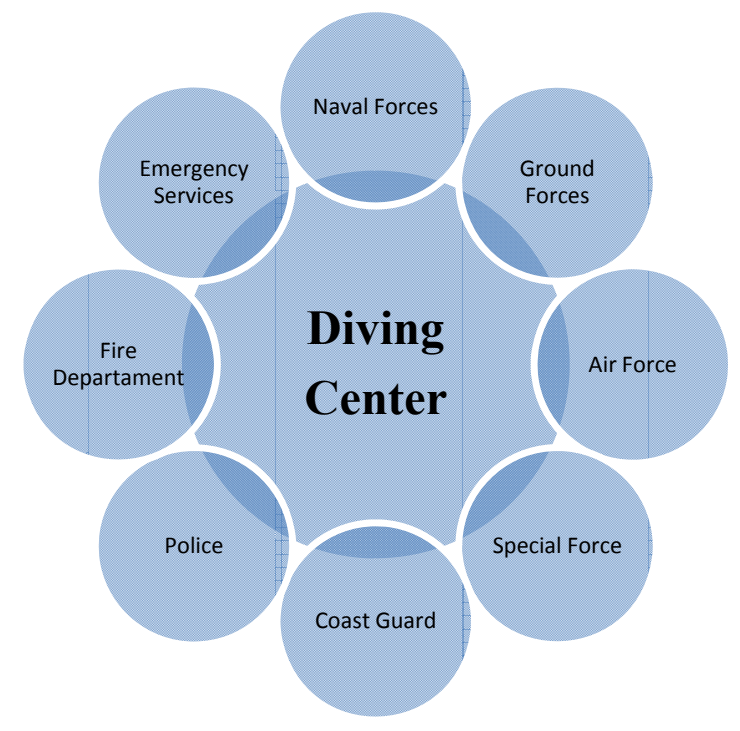

Figure no. 1: National structures collaborating with the Diving Center for diver training

(Source: Chiripuci, Stanciu \& Fleșer, 2020)

Table no. 1

Diver missions and appropriate actions to fulfill them

\begin{tabular}{|c|l|l|}
\hline $\begin{array}{c}\text { Nr. } \\
\text { crt. }\end{array}$ & \multicolumn{1}{|c|}{ Mission } & \multicolumn{1}{c|}{ Action } \\
\hline 1 & $\begin{array}{l}\text { Training military and civilian divers to } \\
\text { obtain the practical skills necessary for } \\
\text { joint missions of allied divers in the } \\
\text { Black Sea basin. }\end{array}$ & $\begin{array}{l}\text { Creating a training base for professional } \\
\text { divers, close to the Black Sea coast, to more } \\
\text { easily ensure the necessary logistics. }\end{array}$ \\
\hline 2 & $\begin{array}{l}\text { Improving its own infrastructure, in the } \\
\text { context of transforming the Diving } \\
\text { Center into a European Diving Training } \\
\text { Center, according to the "European Union } \\
\text { Network of Diving Centers" project of } \\
\text { the European PESCO program. }\end{array}$ & $\begin{array}{l}\text { The endowment of the new training ground } \\
\text { must ensure the harmonization of training } \\
\text { conditions for divers of all countries } \\
\text { participating in the future European Diving } \\
\text { Training and Training Center. }\end{array}$ \\
\hline
\end{tabular}




\begin{tabular}{|c|c|c|}
\hline $\begin{array}{l}\text { Nr. } \\
\text { crt. }\end{array}$ & Mission & Action \\
\hline 3. & $\begin{array}{l}\text { Diving training at the depth level } \\
\text { specific to their qualification. }\end{array}$ & $\begin{array}{l}\text { Creating a step-by-step training base, on } 3 \\
\text { depth levels: } \\
\text { - Level 1: depths between }-5 \text { and }-7 \mathrm{~m} \text {; } \\
\text { - Level 2: depths between }-15 \text { and }-17 \mathrm{~m} \text {; } \\
\text { - Level 3: depths between }-20 \text { and }-25 \mathrm{~m} \text {. }\end{array}$ \\
\hline 4 & $\begin{array}{l}\text { Accommodating working divers with } \\
\text { electric, welding, hydraulic tools, etc. }\end{array}$ & $\begin{array}{l}\text { Level } 1 \text { will be provided with } 2-3 \text { work } \\
\text { tables, at which divers, without feeling } \\
\text { the constraint of deep depths, will perform } \\
\text { the accommodation with various specific } \\
\text { work tools. }\end{array}$ \\
\hline 5 & $\begin{array}{l}\text { Specific training for closed / semi- } \\
\text { closed circuit divers. }\end{array}$ & $\begin{array}{l}\text { Level } 1 \text { will be equipped with a narrow tube } \\
\text { structure, intended for training divers with } \\
\text { closed / semi-closed circuit. }\end{array}$ \\
\hline 6 & $\begin{array}{l}\text { Practicing underwater work activities } \\
\text { (cutting, welding, handling hydraulic } \\
\text { tools, etc.). }\end{array}$ & $\begin{array}{l}\text { Level } 2 \text { will include different objects that } \\
\text { can be the object of the real intervention of } \\
\text { a diver (mines, torpedoes, flanges, anchor, } \\
\text { anchor chain, etc.) }\end{array}$ \\
\hline 7 & Simulation of wreck intervention. & $\begin{array}{l}\text { At Level } 2 \text { there will be a container where } \\
\text { the diver will enter for training in order } \\
\text { to identify and find different objects as well } \\
\text { as for training orientation, entry and exit } \\
\text { skills. }\end{array}$ \\
\hline 8 & Training for backflow operations. & $\begin{array}{l}\text { Level } 3 \text { will include a sunken wreck } \\
\text { intended for training for backflow } \\
\text { operations. }\end{array}$ \\
\hline 9 & $\begin{array}{l}\text { Training for assembling flexible hoses } \\
\text { specific to offshore equipment. }\end{array}$ & $\begin{array}{l}\text { At Level } 3 \text { there will be large diameter } \\
\text { hoses }(50-100 \mathrm{~cm}) \text {, provided with flanges, } \\
\text { for the specific training of their assembly. }\end{array}$ \\
\hline
\end{tabular}

\subsection{Divers, requirements and capabilities adapted to training at the polygon}

Table no. 2 Divers qualifications, requirements and corresponding capabilities

\begin{tabular}{|c|l|l|}
\hline $\begin{array}{c}\text { Diver } \\
\text { qualification }\end{array}$ & \multicolumn{1}{c|}{ Requirement } & \multicolumn{1}{c|}{ Capability } \\
\hline & $\begin{array}{l}\text { Trained for autonomous } \\
\text { equipment (SCUBA), has } \\
\text { minimum qualifications for } \\
\text { protection of the force in the } \\
\text { marine environment, } \\
\text { performs searches, works } \\
\text { and simple maintenance. }\end{array}$ & $\begin{array}{l}\text { Diving activities with autonomous } \\
\text { equipment, with compressed air, at depths of } \\
\text { minimum 15msw and maximum 40msw, } \\
\text { in day / night conditions. Executes: } \\
\text { diver }\end{array}$ \\
$\begin{array}{l}\text { training dives; } \\
\text { simple search and retrieval of objects in the } \\
\text { underwater environment; } \\
\text { technical inspections on the hull; } \\
\text { cleaning live work on the ship, including } \\
\text { simple maintenance operations. }\end{array}$ \\
\hline
\end{tabular}




\begin{tabular}{|c|c|c|}
\hline $\begin{array}{c}\text { Diver } \\
\text { qualification }\end{array}$ & Requirement & Capability \\
\hline Heavy diver & $\begin{array}{l}\text { Trained to be able to evolve } \\
\text { and work underwater, with } \\
\text { the help of specific } \\
\text { equipment, powered and } \\
\text { assisted by a team from the } \\
\text { surface. }\end{array}$ & $\begin{array}{l}\text { Compressed air diving activities, delivered by } \\
\text { umbilical cord, to a depth of } 40 \text { msw, in day / } \\
\text { night conditions. Limited run: } \\
\text { - diving for training; } \\
\text { - search and retrieval operations of objects } \\
\text { and persons in the underwater environment; } \\
\text { - research of the underwater environment; } \\
\text { - collecting and recording information } \\
\text { related to various objectives; } \\
\text { - technical inspections on the hull. }\end{array}$ \\
\hline $\begin{array}{l}\text { Underwater } \\
\text { worker diver }\end{array}$ & $\begin{array}{l}\text { Trained for SCUBA or } \\
\text { surface feeding, to perform } \\
\text { various tasks such as: } \\
\text { moving or anchoring objects } \\
\text { under water, support } \\
\text { (search, penetration, military } \\
\text { searches, placement of } \\
\text { obstacles, destruction, } \\
\text { cleaning of aquariums, } \\
\text { construction and repairs, } \\
\text { safety, search and rescue). }\end{array}$ & $\begin{array}{l}\text { SCUBA diving activities or surface feeding } \\
\text { at depths of minimum } 5 \text { msw and maximum } \\
40 \text { msw, in day / night conditions. Executes: } \\
\text { - diving for training, real or in simulators and } \\
\text { barocameras; } \\
\text { - search and retrieval operations of objects } \\
\text { and persons in the underwater environment; } \\
\text { - underwater works with hydraulically and } \\
\text { pneumatically operated tools; } \\
\text { - welding, underwater cutting, non-destructive } \\
\text { testing of submerged structures; } \\
\text { - demolition with explosives. }\end{array}$ \\
\hline $\begin{array}{l}\text { Salvage } \\
\text { diver }\end{array}$ & $\begin{array}{l}\text { Trained to be able to evolve } \\
\text { and work underwater, with } \\
\text { the help of specific } \\
\text { equipment, for operations of } \\
\text { support, rescue, evacuation } \\
\text { and recovery of material } \\
\text { belonging to allied or enemy } \\
\text { forces: ships, boats, } \\
\text { equipment for reuse, repair } \\
\text { operations. }\end{array}$ & $\begin{array}{l}\text { Diving activities with respiratory mixtures at } \\
\text { depths over } 20 \text { msw, with surface feeding or } \\
\text { with the diving assembly, in day / night } \\
\text { conditions. Performs underwater work } \\
\text { included, but not limited to: } \\
\text { - diving for training real; } \\
\text { - search and retrieval operations of objects } \\
\text { and persons in the underwater environment; } \\
\text { - underwater research: } \\
\text { - underwater works with hydraulically and } \\
\text { pneumatically operated tools; } \\
\text { - welding, underwater cutting, non-destructive } \\
\text { testing of submerged structures; } \\
\text { - complex inspections, including wreck } \\
\text { inspections; } \\
\text { - complex maintenance operations. }\end{array}$ \\
\hline $\begin{array}{c}\text { Naval } \\
\text { Exposal } \\
\text { Ornance } \\
\text { Disposal } \\
\text { (EOD) diver }\end{array}$ & $\begin{array}{l}\text { Trained for military/counter- } \\
\text { mine diving capability }\end{array}$ & $\begin{array}{l}\text { Performs shallow diving activities with } \\
\text { closed circuit oxygen or mixed gas } \\
\text { underwater breathing apparatus for: } \\
\text { - demolition with explosives; } \\
\text { - searches and inspections of mines; } \\
\text { - neutralization and destruction of mines; } \\
\text { - underwater land remediation works; } \\
\text { - specific explosives combat training. }\end{array}$ \\
\hline
\end{tabular}




\begin{tabular}{|c|l|l|}
\hline $\begin{array}{c}\text { Diver } \\
\text { qualification }\end{array}$ & \multicolumn{1}{|c|}{ Requirement } & \multicolumn{1}{c|}{ Capability } \\
\hline & & $\begin{array}{l}\text { Performs shallow diving activities with } \\
\text { closed circuit oxygen or mixed gas } \\
\text { underwater breathing apparatus for: }\end{array}$ \\
$\begin{array}{c}\text { Special } \\
\text { Warfare }\end{array}$ & $\begin{array}{l}\text { Trained for autonomous } \\
\text { diving operations during } \\
\text { (SPECWAR) } \\
\text { forces diver }\end{array}$ & $\begin{array}{l}\text { combat missions } \\
\text { recording information related to various } \\
\text { objectives; } \\
\text { training specific to combat forces } \\
\text { - cutting and destroying obstacles }\end{array}$ \\
\hline
\end{tabular}

\section{Location, structure and equipment of the polygon}

\subsection{Location}

For the location of the landfill, two sheltered submarine locations were studied, protected from the activities of the port operators:

- location 1 on a large area, but with small natural depths;

- location 2 on a smaller area, but with natural depths close to those conditioned in the project.

For location 1 the plane of the polygon is the one in (Figure no. 3). Extensive and expensive hydrotechnical work is required to cover the depth threshold parameters. The seabed in this district is sandy and there is a danger of clogging after finishing the landscaping works.

Location 2 (Figure no. 4) can be arranged only by demolition works, on a natural stone carpet and by exploiting the natural deep steps. The nearby dike provides very good shelter. The polygon profile complies with the requirements of (Table no. 1).

Following the comparative analysis, location 2 was selected. Its advantages are:

- the area is physically isolated from the ships in the port and from the active berths, for the safety of the personnel;
- it is sheltered by the neighboring relief, for the development of specific military activities (demolition, detonation of explosives);

- location at a distance from other objectives ensures sound insulation;

- natural depths evolve slowly and are close to training levels;

- good underwater visibility;

- easy access by car and by sea;

- running water supply nearby;

- the possibility of switching to electricity in the vicinity;

- video surveillance of the area;

- quick access to and from the military port of Constanta;

- the existence of a flat surface on the shore, which would allow the location of the divers' equipment;

- the moderate influence of sea currents on divers' activities;

- low impact on the marine environment.

\subsection{Structure}

The profile of the submarine polygon (Figure no. 4) consists of 3 cobbled platforms, at the 3 depth levels in (Table no. 1). Natural stone platforms ensure the stability of submerged equipment. 


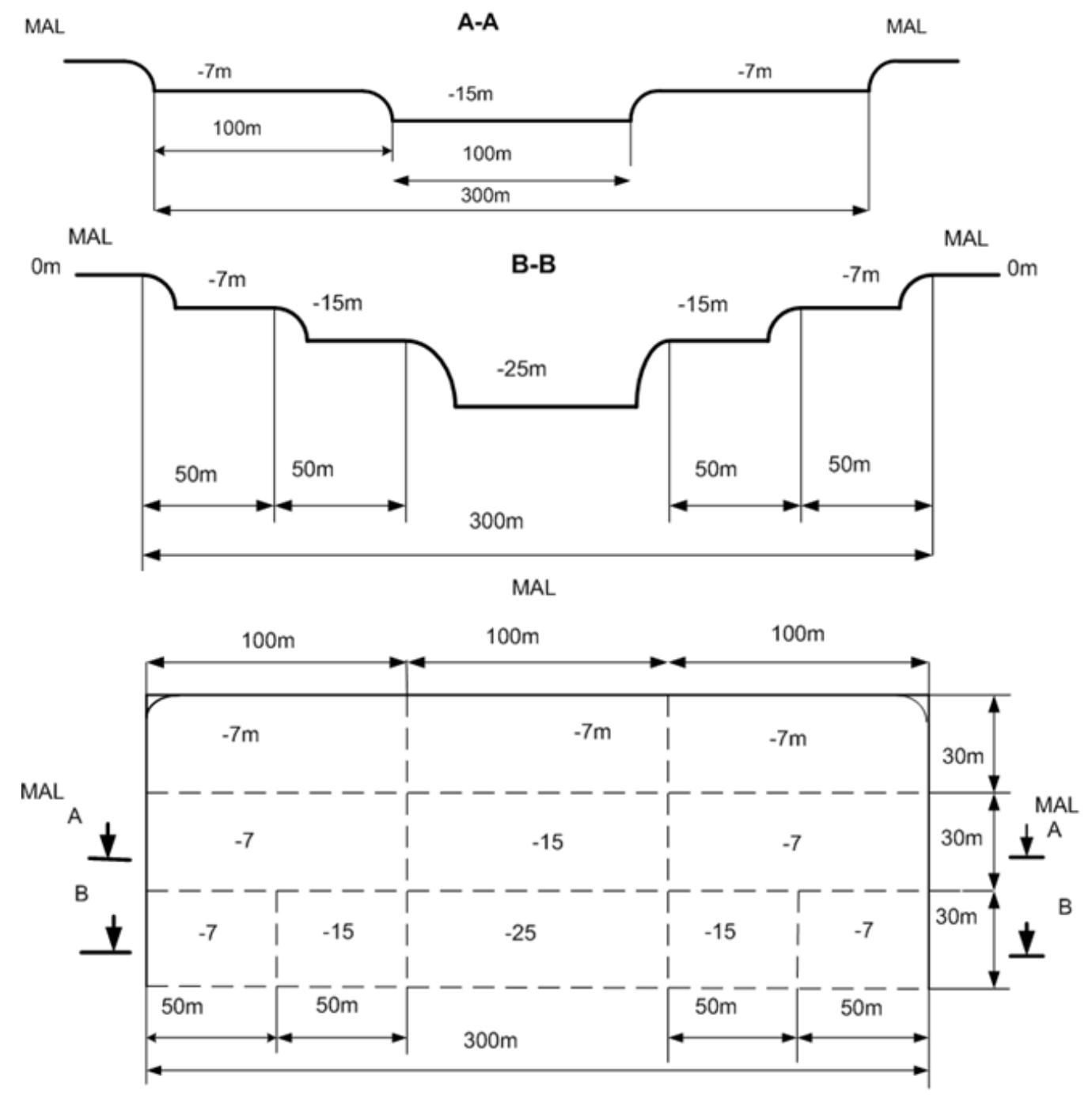

Figure no. 3: Polygon profile at location 1

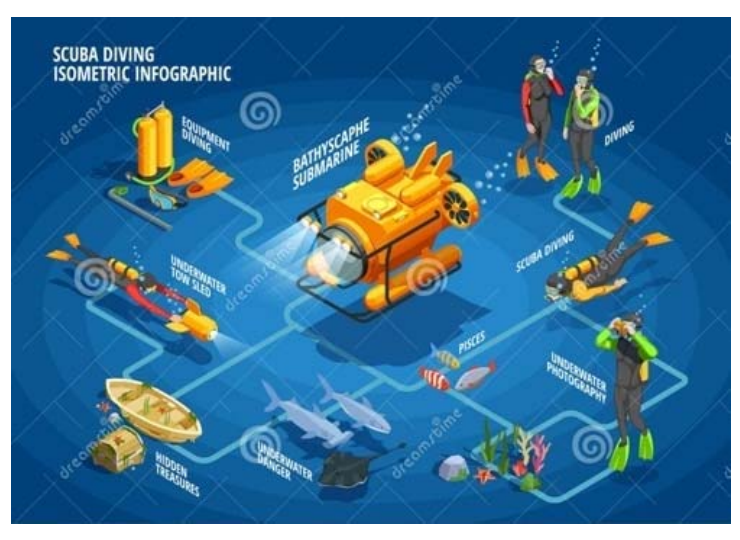

Figure no. 2: SCUBA training (Source: Macrovector, 2019)

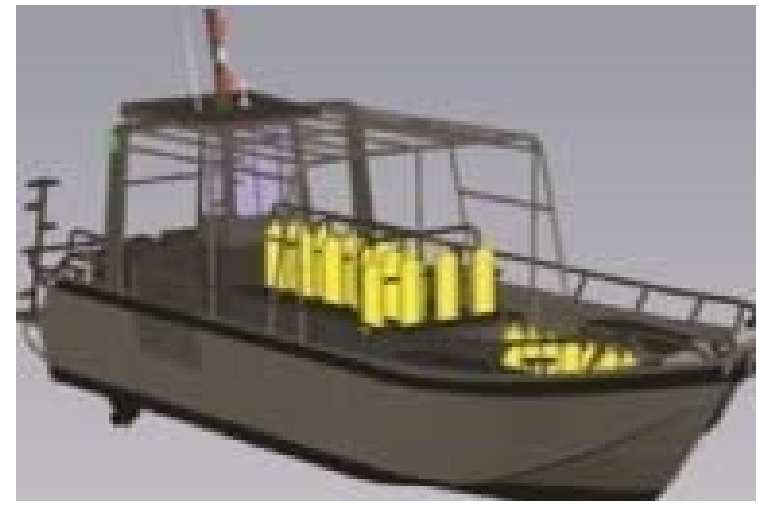

Figure no. 5: Support boat for surface equipment 


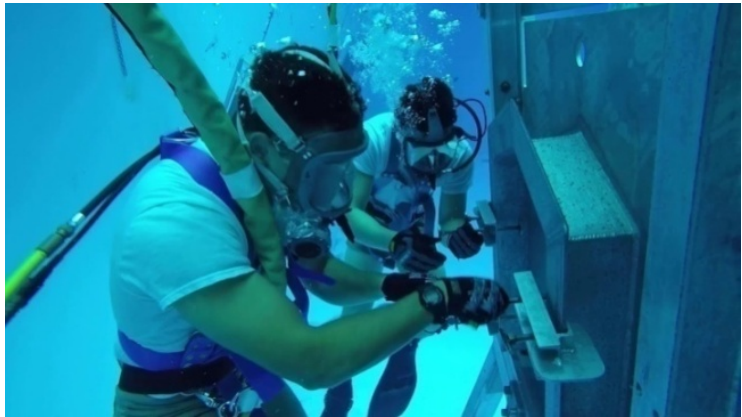

Figure no. 6: Training for mechanical works (Source: Environmental impact)

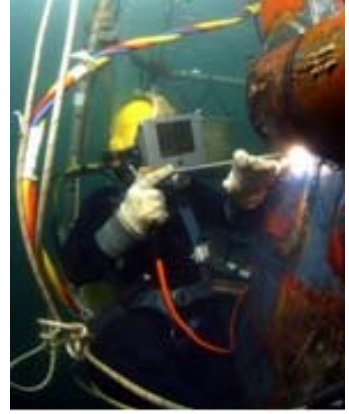

Figure no. 7: Practice of welding operations (Source: Travis, 2020)
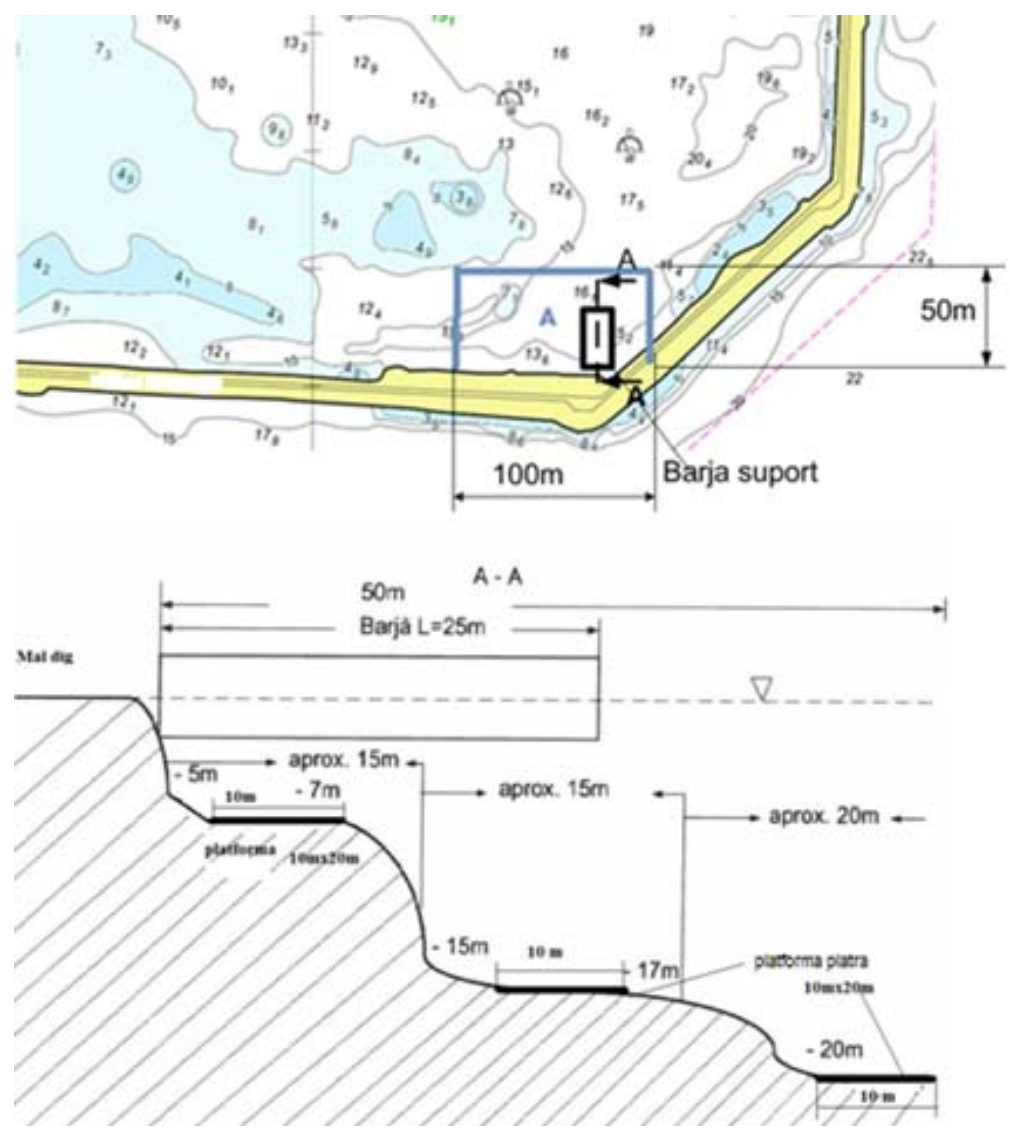

Figure no. 4: Location and profile of the submarine polygon in location 2 with natural deep platforms

For the extension of the training area, a support barge will be used (Figure no. 5), of approximate dimensions $\mathrm{L} \cong 25 \mathrm{~m}$ and $1 \cong 15 \mathrm{~m}$, on which the surface equipment will be placed, served by the surveillance team, according to the diving norms. At the same time, starting from the end of the barge, divers with umbilical cord equipment can perform diving offshore, up to a depth of $25 \mathrm{msw}$. The barge will be equipped with:

- 1 modern equipment for tracking and locating divers;

- 1 electric generator;

- 1 air compressor for diving;

- 2 diving equipment for deep sea;

- 1 diving basket;

- 2 underwater scooters;

- 1 container for surface equipment. 
Level 1 will be arranged with:

- 2 professional workbenches, with vise;

- 2 pipe fixing and adjustment modules;

- 1 underwater cutting and welding equipment;

- 1 hydraulic equipment for cleaning submerged structures (brush-kart);

- 1 narrow tube structure, designed for training closed / semi-closed divers.

Level 2 will be arranged with:

- 1 moored container, for simulating the rescue activity, equipped with depth and roll sensors and for identifying and finding different objects, as well as for training orientation, entry and exit skills.

- various real objects (mines, torpedoes, flanges, anchor, anchor chain, etc.) for search training.

Level 3 is intended for backflow training and deep diving exercises. It will be equipped with:

- 1 wreck sunk at $20 \mathrm{msw}$;

- $1 \mathrm{tf}, 2 \mathrm{tf}, 4 \mathrm{tf}$ discharge balloons;

- flexible hoses with large diameters $(50-100 \mathrm{~cm})$, specific to offshore equipment, intended for assembly and disassembly exercises.

- 1 diving basket.

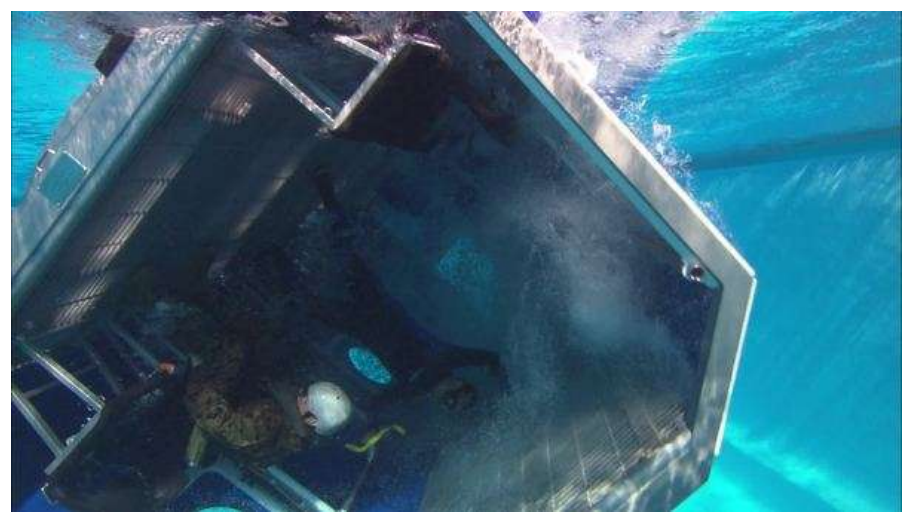

Figure no. 8: Simulation of rescue activity by wreck intervention, using a container (Source: Pawlyk, 2020)

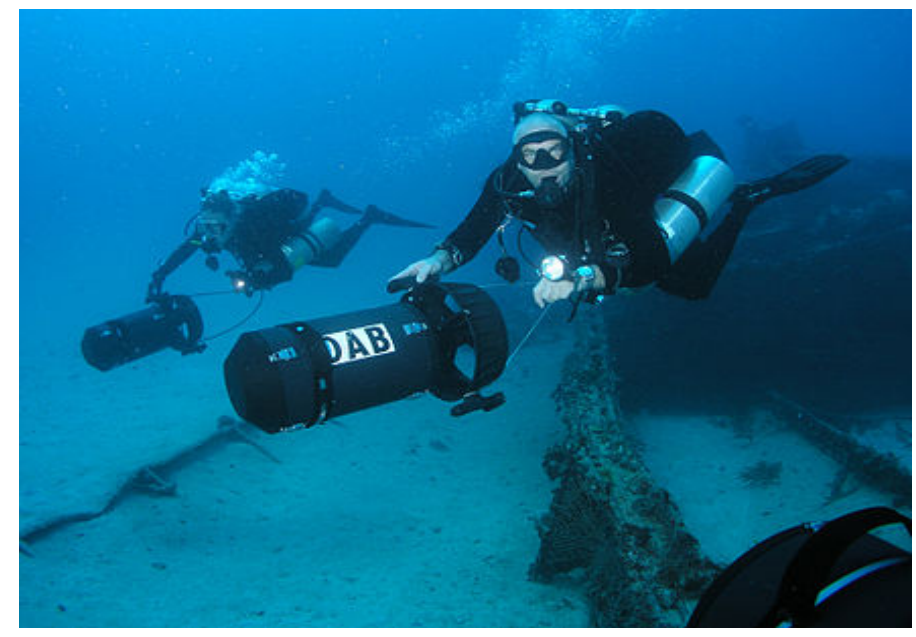

Figure no. 9: Underwater scooter search lessons (Source: Diving with Scooters-Blog-Kapitol Reef) 


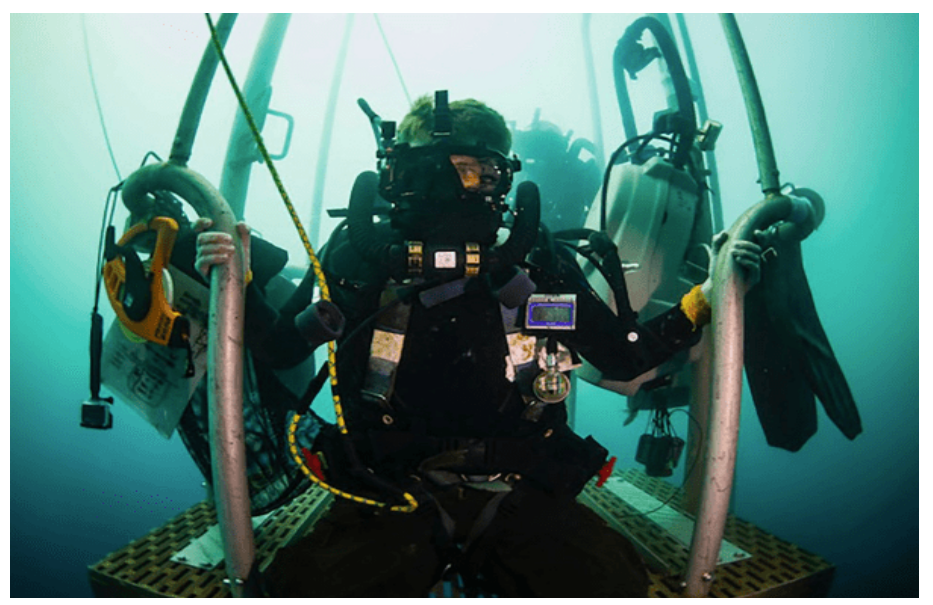

Figure no. 10: The descent of the deep divers with the help of the diving basket

(Source: Travis, 2020)

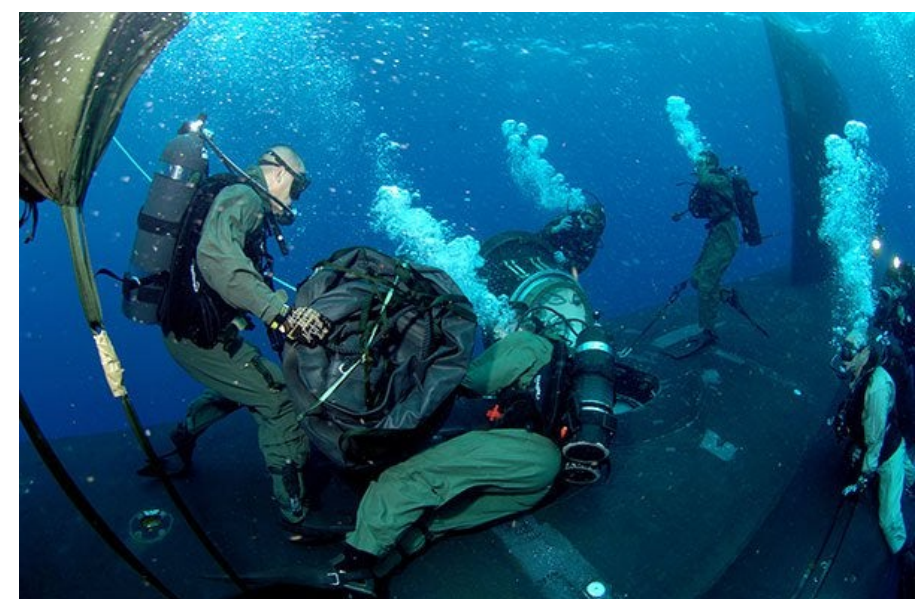

Figure no. 11: Self-rescue exercises from the training wreck

(Source: Navy SEALs and Navy Divers Conducting Lock Out Training!, 2013)

\section{Conclusions}

In the context of the complete modernization of the Diving Center by replacing baroque rooms and hyperbaric installations with new ones and by building the swimming pool, the third project implemented within the European security program PESCO, wave 3, European Unio Network Diving Centers, respectively
"The development of a complex polygon for the instruction, preparation and training of professional divers", contributes to increasing the capacity in the area of interest of the Black Sea. The training ground will be able to be used in the joint training missions of NATO allied forces, to increase the security of the coastal area. 


\section{REFERENCES}

Chiripuci, N., Stanciu, T., \& Fleșer P. (2020). European Diving Training Center (EDTC). Annals of the Academy of Romanian Scientists Series on Engineering Sciences, Vol. 3, Issue 1, 5-17.

Diving with Scooters-Blog-Kapitol Reef, available at: https://www.pinterest.com/ $\mathrm{pin} / 308707749435392890 /$

Environmental impact, available at: https:/www.wikiwand.com/en/ Underwater diving

Macrovector. (2019). Scuba diving snorkeling isometric flowchart with underwater divers in suits with diving equipment and fis, available at: https://www.google.com/ dreamstime.com

Navy SEALs and Navy Divers Conducting Lock Out Training! (2013). Available at: https://www.reddit.com/r/scuba/comments/12rlqt/navy seals and navy divers conducting 1 ock out

Pawlyk, O. (2020). Special Tactics Airman Dies During Combat Dive Training, available at: https://www.military.com/daily-news/2020/03/20/special-tactics-airman-diesduring-combat-dive-training.html

Travis, R. (2020). Navy Diver (ND): Career Details, available at: https://www.operationmilitarykids.org/navy-diver-nd/ 